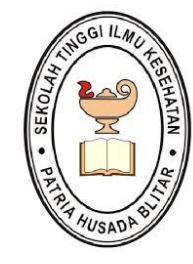

JCSH

JOURNAL OF COMMUNITY SERVICE

FOR HEALTH

http://juda.phb.ac.id/index.php/jcsh

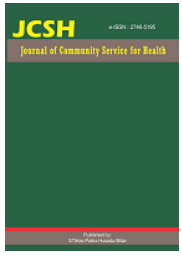

\title{
The Mentoring of Health Cadres in Toddler Caring of Durian Posyandu at Karangduren Village, Pakisaji District
}

\author{
Ririn Harini ${ }^{1}$, Juwitasari ${ }^{2}$ \\ ${ }^{1,2}$ Faculty of Health Science, Universitas Muhammadiyah Malang, Indonesia
}

\section{Article Information}

History Article:

Received, 14/01/2021

Accepted, 16/04/2021

Published, 05/05/2021

\section{Keywords:}

Training, Toddler Care, Cadres, Posyandu

\begin{abstract}
Fifteen health cadres at Karangduren village, Pakisaji, southern part of Malang East Java, face problems such as the lack of ability and confidence in providing health information to the mothers who visit the posyandu regarding to baby and toddler care. This community service was conducted to provide skill provisions for toddler health cadres in performing education for mothers of toddler as well as skill learning about baby care. Therefore, it was done by having mentoring and provisioning to the health cadres with 3 activities based on the problems which included the unavailability of health support facilities for cadres by having the mentoring activity for the health cadres, completing the lack of infrastructure and the unavailability of trained health cadres from the mothers of toddler. The results obtained from the mentoring showed significant improvement of knowledge from the entire participants of mentoring, which could be observed from the properly applied skills in baby/toddler care. It could also be observed from the facilities added such as the educational game tools (APE) which proved that cadres can select games that stimulate toddlers in improving their cognitive, affective and motor growth. Overall, it could be stated that the program achieved $90 \%$ of achievement which could be aimed by matters such as the target of the toddler health cadres and the training that were proceeded smoothly, the $90 \%$ attendance of cadres, and the significant improvement of knowledge and skills that were showed through the training and mentoring of toddler health cadres.
\end{abstract}

Correspondence Address:

Universitas Muhammadiyah Malang - East Java, Indonesia

E-ISSN : 2746-5195

Email: ririn_harini@umm.ac.id

DOI: 10.26699/jcsh.v2i1.ART.p020-26

This is an Open Access article under the CC BY-SA license (http://creativecommons.org/licenses/by-sa/4.0/) 


\section{INTRODUCTION}

Integrated service post (Posyandu) is a form of community empowerment in Community Based Health Efforts which is carried out with the full participation of the community which aims to empower and provide convenience to the community to obtain services for mothers, infants and toddlers (Zaki et al., 2018). The benefits of having Posyandu include making it easier to get information on maternal, infant and toddler health services, being able to monitor the growth of children under five so that they do not suffer from nutritional problems (Ambarita et al., 2019).

Toddler health cadres often face problems such as the lack of ability and confidence in providing health information to the mothers who visit the posyandu (Integrated Health Post) regarding to baby and toddler care. Posyandu cadres are the spearhead of toddler health services. Health cadres that have never participated in certain training in performing baby care and some incomplete facilities in conducting education by health cadres are also the often problems faced by toddler health cadres (Salamah \& Sulistyani, 2018).
National data from Riskesdas 2013 shows that $36.8 \%$ of children under five years of age (toddlers) are stunted (short and very short, measured by height for age). This indicator shows the occurrence of malnutrition in the long term or chronic due to high morbidity or low food intake (Iswarawanti, 2010). Cadres are expected to be able to bridge the gap between health workers/experts with the community and help communities identify, address and respond to their own health needs (Sari et al., 2017). Cadres are also expected to be able to provide information to authorized health officials who may not be able to reach the community directly, and to be able to encourage health officials in the health system to understand and respond to community needs. Cadres can help mobilize community resources, advocate for the community and build local capacities (Dewi et al., 2020).

Therefore, mentoring toddler health cadres with the characteristics of cadres who do not yet have the ability to bridge health experts with mothers and toddlers, with low educational backgrounds and communication skills that are not maximized is conducted in 
order to solve the existing problems (Dietetik et al., 2015). As for the purpose of this research, it is to provide skill provisions for toddler health cadres in performing education for mothers of toddler about baby care skills such as ways on how to bathe babies, umbilical cord treatment, baby massage and other additional knowledge regarding to the complete education of immunization (Posyandu, 2018).

\section{METHODS}

This community service was conducted at Durian posyandu by providing mentoring and provisioning to the health cadres with 3 problem references which includes; 1) the unavailability of health support facilities for cadres by having the mentoring activity for the health cadres and completing the lack of infrastructure; 2) the unavailability of trained health cadres from the mothers of toddler causing the improvement of the health cadres skills through training; 3) the education of health and skill promotion of baby care through training and mentoring.

The mentoring and provision methods are as follows: 1) The initial identification of the problems found was in the form of a lack of knowledge and skill levels about under-five health among mothers of health cadres at the durian posyandu, Karangduren Pakisaji Village, Malang Regency. 2) Provide children's health materials and basic care skills for toddlers' health to cadres and mothers of productive age at the durian posyandu, Karangduren Pakisaji Village, Malang Regency and motivate them to be aware of maintaining the health of toddlers 3) Making service products in the form of toddler health media 4) Strengthening materials, concepts and skills about toddler health.

Community service carried out in the Durian Posyandu, Karangduren Pakisaji Village, Malang Regency, East Java, began by conducting situation analysis, problem analysis and forming partnerships with health cadres. Increased partnership with the community in community service is achieved with the approval of the local village head, and all health cadres. The implementation of this community service uses the concept of strengthening posyandu, by increasing the ability of the mother of the toddler to prosper herself and her toddler.

The method in the community 
service program uses the experimental method with the one group pretest posttest method. The first pretest was conducted to measure the level of knowledge of cadres about toddler Posyandu under five years old, maternal, infant and toddler health, nutrition in children and infectious diseases in children.

Then the cadres received training related to Posyandu for toddlers for 2 days. Posttest is carried out after the training activities are completed. The program is implemented in the population of all cadres of the Durian Karangduren posyandu. The sampling technique used a total sampling of 15 cadres. Data collection techniques are carried out on the first day of training for all cadres given a test. Then the treatment was obtained by the entire sample by attending training for 2 days by presenting resource persons from the
Children Health Department lecturers of the nursing study program. Post test was given to all participants on the last day of training. Data analysis used the T test to measure the level of difference in knowledge of cadres before the training was carried out with after the training was carried out.

\section{RESULTS}

The results obtained from the community service showed significant improvement the level of knowledge from the entire 15 participants of mentoring and training toddler health cadres, which can be observed from the properly applied skills in baby/toddler care from $48 \%$ to $89 \%$. It can also be observed from the facilities added such as the educational games which proved that cadres can select games that stimulate toddlers in improving their cognitive, affective and motor growth. The descriptions are provided below in Table 1:

Table 1.Activities and Achievements of the Community Service

\begin{tabular}{|c|l|}
\hline \multicolumn{1}{|c|}{ Period } & \multicolumn{1}{|c|}{ Activities And Results Achieved } \\
\hline 15 June 2019 & $\begin{array}{l}\text { Internal coordination meeting with the IbM Fikes UMM team in } \\
\text { maximizing the work program in detail and the job division based on the } \\
\text { survey done } \\
\text { Result: An agreement achieved regarding on the job description for each } \\
\text { member }\end{array}$ \\
\hline 22 July 2019 & $\begin{array}{l}\text { Training material and counseling arrangement that will be delivered in the } \\
\text { mentoring of babyltoddler care implementation } \\
\text { 1. How to bathe baby/toddler and treat umbilical cord } \\
\text { 2. Deliver the material regarding on } A P E \text { (educational game tools) }\end{array}$ \\
\hline
\end{tabular}




\begin{tabular}{|c|l|}
\hline 10 August 2019 & $\begin{array}{l}\text { Internal coordination meeting II discussing about the technical field plans, } \\
\text { the preparation of logistics, and the tools and used properties identification }\end{array}$ \\
\hline 25 August 2019 & $\begin{array}{l}\text { Internal coordination meeting III with the partners } \\
\text { Result: Time/training schedule and location agreement with the health } \\
\text { cadres at Durian posyandu, and do the Pretest for all cadres. }\end{array}$ \\
\hline $\begin{array}{c}\text { 6 September 2019 } \\
\text { At Durian }\end{array}$ & $\begin{array}{l}\text { Training I Starts at : 09.00 - 14.00 WIB, material : } \\
\text { 1. Material on Baby/Toddler Care } \\
\text { 2. Demonstration on (bathing babies/toddlers, treating umbilical cord) } \\
\text { 3. Delivery ofmaterialonGame Stimulation for Toddlers anddistribution of } \\
\text { APE(educational game tools) at Durian posyand and followed by final } \\
\text { post test for all 15 cadres. }\end{array}$ \\
\hline
\end{tabular}

Data source: Primary data, processed on 2020

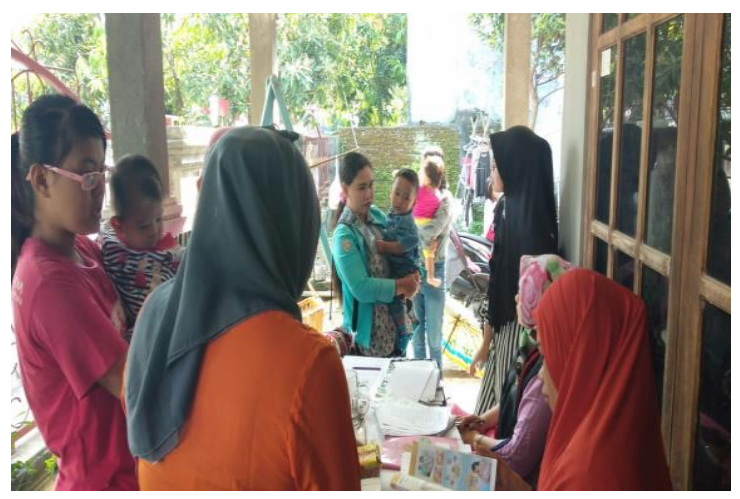

\section{DISCUSSION}

In the beginning of this community service, coordination meetings were conducted with the team to discuss about the training material and counseling arrangement along with the mentoring on the implementation of baby/toddler care (ways on bathing babies/toddlers, umbilical cord treatment, delivery of material on educational game tools). This training started on the $6^{\text {th }}$ September 2019 at Durian posyandu by do the pretest for 15 cadres. The results achieved from the community

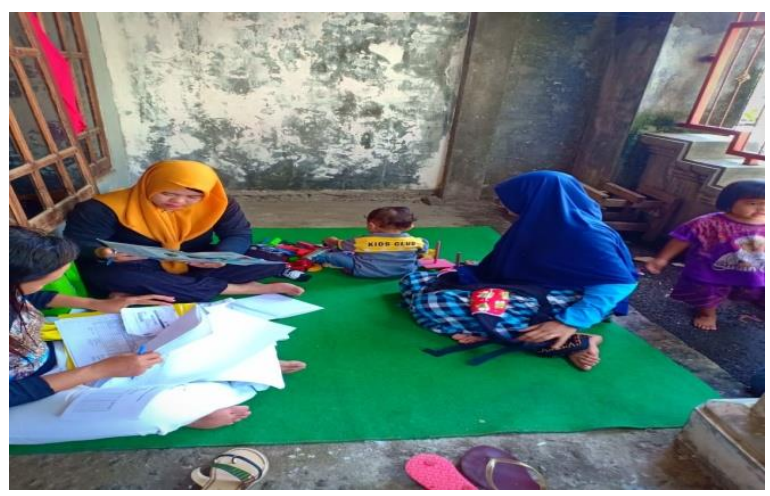

service was the significant improvement of knowledge from the entire participants (from $48 \%$ to $89 \%$ ) of mentoring and training toddler health cadres which were observed from the ability in applying the skills in baby/toddler care properly and correctly.

\section{CONCLUSION}

It can be summed up that in general work programs have been compiled based on the improvement of current situation including the disbursed fund. Throughout 
the entire work program, it can be stated that the program achieved $90 \%$ of achievements. This can be achieved because of matters such as the target of the toddler posyandu cadres, the training that was conducted very well, the $90 \%$ attendance of cadres, and also the facilities added such as the educational games which proved that cadres can select games that stimulate toddlers in improving their cognitive, affective and motor growth. There are some suggestions from the team and the community service members for the toddler health cadres, which are; perform a better coordination and socialization and also conduct education as often as possible to the mothers of toddler in order to improve the skill and ability.

\section{SUGGESTION}

The significant role of cadres in Durian Posyandu empowering communities to reduce infant and toddler mortality and morbidity rates in Karangduren. However, as the health cadres they should be: 1) Increase their motivation and commitment of cadres to keep the minimum competencies. 2) Cadres of Durian Posyandu should have the basic requirements of both knowledge and skills so that they can be effective in carrying out and identifying their roles. 3) The health cadres should able to actively update the latest issue of maternal, neonatal, and children health in order to maintain their excellent services.

\section{REFERENCES}

Ambarita, L., Husna, A., \& Sitorus, H. (2019). Pengetahuan Kader Posyandu, Para Ibu Balita Dan Perspektif Tenaga Kesehatan Terkait Keaktifan Posyandu Di Kabupaten Aceh Barat. Buletin Penelitian Sistem Kesehatan, 22(3), 147-157.

https://doi.org/10.22435/hsr.v22i3.65

Dewi, M. U. K., Mustika, D. N., \& Kusumawati, E. (2020). Penyuluhan Tentang Asi Eksklusif, Vitamin a , Dan Stunting Di Posyandu Anggrek Rw 04 Dusun Teseh Kelurahan Meteseh Kecamatan Tembalang Kota Semarang Counseling of Exclusive Breastfeeding , Vitamin a, and Stunting in Posyandu Anggrek Rw 04 Dusun Teseh Ke. Jurnal Pengabdian Masyarakat Kebidanan, 2(2), 50-55. http://103.97.100.145/index.php/JPMK /article/view/5949

Dietetik, A., Paramasan, P., \& Selatan, K. (2015). Studi ketidakaktifan kader posyandu di Wilayah Kerja. 3, 60-67.

Iswarawanti, D. N. (2010). Kader Posyandu: Peranan Dan Tantangan Pemberdayaannya Dalam Usaha Peningkatan Gizi Anak Di Indonesia. 13(04), 169-173.

Posyandu, K. (2018). Kader Posyandu / Kesehatan? 2(April), 223-238.

Salamah, N., \& Sulistyani, N. (2018). Pelatihan Peran Serta Kader Posyandu Dalam Pemberian Edukasi Kepada Masyarakat. Jurnal Pemberdayaan: Publikasi Hasil Pengabdian Kepada Masyarakat, 249. 
https://doi.org/10.12928/jp.v2i2.393

Sari, P., Nirmala, S. A., \& Diah. (2017). Evaluasi Pelayanan Revitalisasi POSYANDU dan Pelatihan Kader Sebagai Bentuk Pengabdian Masyarakat. Journal of Chemical Information and Modeling, 53(9), 1689-1699.

Zaki, I., Farida, F., \& Sari, H. P. (2018). Peningkatan Kapasitas Kader Posyandu
Melalui Pelatihan Pemantauan Status Gizi Balita. In Jurnal Pengabdian kepada Masyarakat (Indonesian Journal of Community Engagement) (Vol. 3, Issue 2, p. 169). https://doi.org/10.22146/jpkm.28595 